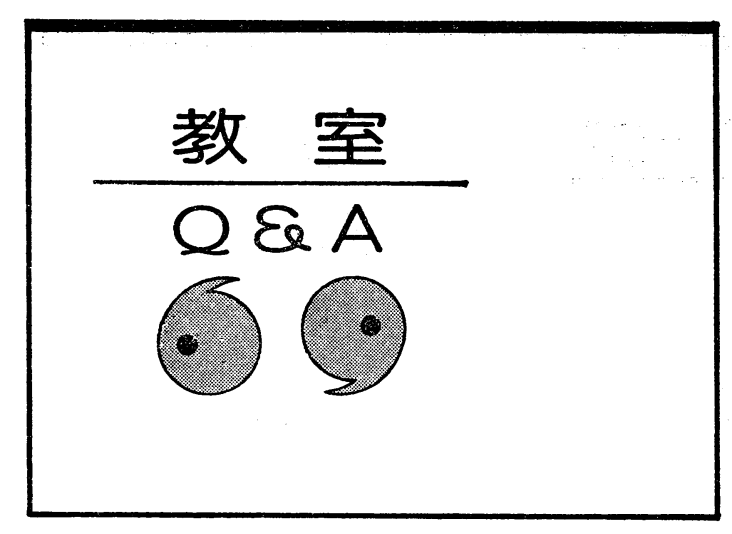

\section{[Q] コンクリートの凍害について教え}

\section{て下さい。}

[A] コンクリートの凍害というのは，コンクリート 中の水分方凍結により, その体積を約 $9 \%$ 程増加して周 囲のコンクリートに微細ひびわれを発生させ，さらにそ の微細ひびわれに浸透した水の凍結により, コンクリー 卜の破壊が進行して崩壊に至る現象を言います。このよ らにコンクリートが涷害を受けるには, コンクリート中 に水分（85 90\%以上）があること, 凍結融解を繰り返 すことなどが条件となります。これらは外的要因と呼ば れ，長谷川により凍害危険度の分布図 ${ }^{1}$ が作成されてい るほか, 北海道に施工される建築構造物には, 雪解け水 の処理について, コンクリートにしみこまないよう配慮 したものが多いと言われます。

一方, 構造物が受ける厳しさ (外的要因) に釣り合っ た凍害抵抗性を確保するために, コンクリートの配合, 材料などの内的要因を適切に選択することも非常に大切 です。

コンクリートが凍害を受けるしくみについては, 凍結 による水の移動圧力のほか, コンクリート中の気泡性状, 自由水の拡散, 浸透圧, 水やコンクリート構成村の熱膨 張係数の相違など, 種々の要因が組み合わさって生ずる ので, 諸説があり, まだ定まったものはありません。

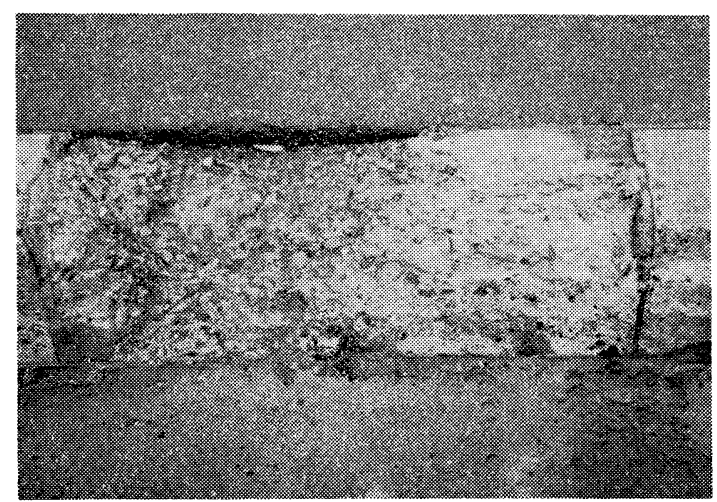

ここでは代表的なものとして, Powers の水圧説を 紹介します。それは，「飽水状態のセメントペーストが $0^{\circ} \mathrm{C}$ 以下に冷却されると, 径の大きい毛細管空隚”(平均 $5000 \AA$ 少)の水から涷り始め, 温度が下がるに従って, 小さい空隚中のそれが凍結する。径の大きい空隚の水が 小空隚の水の膨張移動を阻害し, 水圧を生じさせる。セ メントペーストは, 小さいが透水性をもっているため, 毛細管空嚐の圧力水が周囲に排出される。近くに連行空 気泡 $(2 \mu \sim 2 \mathrm{~mm})$ 分あ机ばそれに浸入し, 圧力は緩和 される」といらものです。

圧力水が移動できる範囲は $200 \mu$ 程度と言われ, ACI で注気泡間隔係数 (平均気泡間距離) $200 \mu$ 以下として いますが, 小林は種々の実験を重ねた結果, 日本では $250 \mu$ 以下とすれば十分としています2)。

凍害を受けるおそれのある場所に建設するコンクリー 卜を空気量 3〜6\% (図一1) の $\mathrm{AE}$ コンクリートとする ことが推奖されるのはこのためですが, 混和剤の種類に よっては粗大な空気泡となり，気泡間隔係数を満足でき ないものもあるので注意が必要です。

一方, 毛細管空隚には, 径の小さいものから飽水し, 径の大きい毛細管空偿は飽水しにくいという性質もあり ます。コンクリートに凍害を生じさせやすい危険な径の 範囲があるように考えられます。各研究者によると, 半 径 1000 10000 A 程度がそれにあたると言われます。 凍害を生じさせないためには $1000 \AA$ 以下の毛細管空 隚の割合を多くすればよいということにもなります。湿 潤養生を十分すること（図一2，3，表一1），W/C を小 さくすること（図一4, 表一2）は，その点で効果が大き いということができます。

コンクリートの約 7 割を占める骨材の影響も大きいも

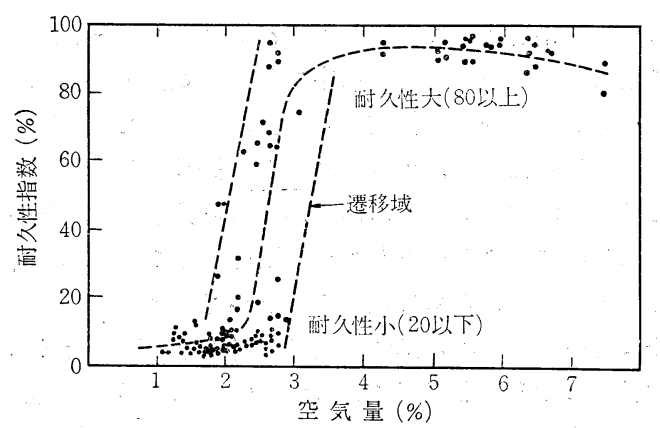

$$
\text { 耐久性指数 } D F=\frac{P N}{M}(\%)
$$

$D F$ : 供試体の耐久性指数

$P:$ 凍結融解 $N$ サイクルにおける相対動弾性係数

$N$ :Pの值が特定の值(一般に60\%)となるまでのサイクル数, または試験終了したときのサイクル数

$M:$ 試験を終らせる特定のサイタル数(一般に 300 回, JIS A 6204 では200回)

図一1 各種の骨材, 単位セメント量, 水セメント 比, 空気からなるコンクリートの耐久性 ${ }^{3}$ 

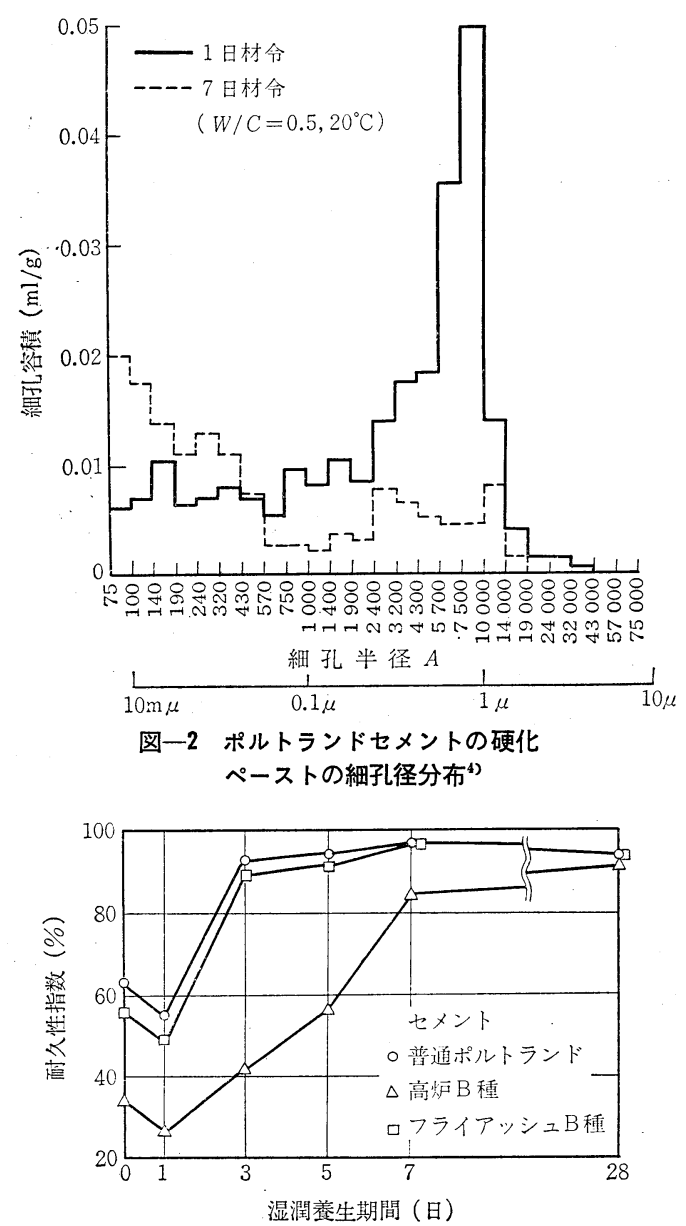

図一3 湿潤養生期間を変えたコン クリートの耐久性指数 ${ }^{5)}$

表一1 コンクリートの湿潤養生日数

(北海道開発局)

\begin{tabular}{|c|c|c|}
\hline $\begin{array}{c}\text { 普通禾ルトランド } \\
\text { 七メント }\end{array}$ & $\begin{array}{c}\text { 早強术ルトラント } \\
\text { セメント }\end{array}$ & 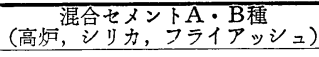 \\
\hline 5 日以上 & 3 日以上 & 7 日以上 \\
\hline
\end{tabular}

のです。骨材自体の凍害も, 凍結時の圧力水の移動で説 明できます。粒径が大きくなれば圧力水の移動が困難と なり，破壞しやすくなるといら訳です。その限界を限界 寸法と呼んで抢り, 吸水率が大きくなるほど, 岩質が弱 いほど小さくなると言われますが，普通の岩石で問題と なることは少ないようです。骨材の物理的性質として JIS A 5005 (コンクリート用砕石) の規格（吸水率 $3 \%$ 以下, 比重 2.5 以上）を満足していることが望ましいと 考えられます。

なお，骨材が原因で涷害を受けを場合には，配合，養 生などでは改善できないので注意を要します。

凍害には，コンクリートの硬化初期に凍結して生ずる 初期凍害というものもありますが，これについては本誌 '81 年 5 月号 (Vol. 19, No. 5) の本欄を参照してくだ さい。

\section{参 考 文 献}

1）長谷川寿夫 : コンクリートの凍害危険度算出と水セメン 卜比限界值の提案，セメント技術年報，Vol. 24，1975

2) 小林正几：コンクリートの凍結融解作用による劣化に関 する 2,3 の考察, コンクリートジャーナル, Vol. 7， No. 9, 1969.9

3) W.A. Cordon : Freezing and Thawing of ConcreteMechanisms and Control, ACI Monograph, No. 4, 1968

4）山田順治・有泉 昌：わかりやすいセメントとコンクリ 一トの知識, 鹿島出版会, 1976

5）前川静男・今井益隆 : 養生程度がコンクリートの耐久性 に与える影響, セメント・コンクリート, No. 345, 1975. 11

6）永倉 正：コンクリートの配合諸条件が凍結抵抗性にお よぼす影響に関する基礎的研究，土木学会論文集，No. $98,1963.10$

（太田利隆）

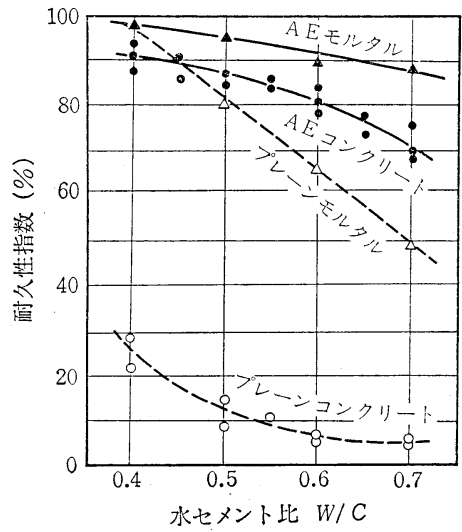

図一4 コンクリートおよびモルタルの水セメ ント比と凍結抵抗性との関係 ${ }^{6)}$
表一2 コンクリートの耐久性を基として水セメント比を定める 場合の $\mathbf{A E}$ コンクリートの最大水セメント比 (\%)

(土木学会)

\begin{tabular}{|c|c|c|c|c|c|c|}
\hline 気象条件 & \multicolumn{3}{|c|}{ 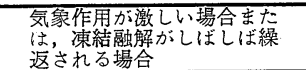 } & \multicolumn{3}{|c|}{ 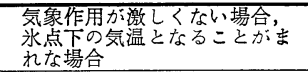 } \\
\hline $\begin{array}{l}\text { 構造物 の 断面 } \\
\text { 䈃出状態 }\end{array}$ & 薄い場合 & 普通の場合 & 厚い場合 & 薄い場合 & 普通の場合 & 厚い場合 \\
\hline 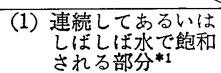 & 55 & 60 & 60 & 55 & 65 & 65 \\
\hline $\begin{array}{l}\text { (2) 普通の䈃出状態に } \\
\text { 劣) } \\
\text { 小場合 }\end{array}$ & 60 & 65 & 65 & 67 & 70 & 70 \\
\hline
\end{tabular}

*1 水路, 水槽, 橋台, 橋脚, 㩲壁, トンネル覆工等で水面に近く水で飽和される部分お よび, これらの構造物のほか，けた，床版等で水面から離れてはいるが, 融雪, 流水, 水しぷき等のため水で飽和される部分

*2 断面の厚さが $20 \mathrm{~cm}$ 程度以下の構造物の部分

*3 マッンフな構造物の表面部分

*4 *2 および*3 に属さない部分 